\title{
研究速報
}

\section{模擬酸性雨に上る植生土㗒の 溶脱成分に関する基礎的研究}

\author{
Eluviated component of ando-soil by artificial \\ acid rain using planted soil column
}

原田浩幸*・ガユミヤーン・ジャワァル*・田中一彦 **・中島重 旗 $*$

\begin{abstract}
The effects of artificial acid rain on eluviated component using the planted soil column and soil column was studied. The column were watered with "rain" having $\mathrm{pH} 4.0$. The concentration of $\mathrm{Ca}^{2+}$, $\mathrm{Mg}^{2+}$ and $\mathrm{Cl}^{-}$in the soil-solution from planted soil-column were higher than that from soil column. The distribution of eluviated total cation in the planted soil-column was no diffence. It could be considerd that effect of acid rain on eluviation was influenced by root zone.
\end{abstract}

\section{要旨}

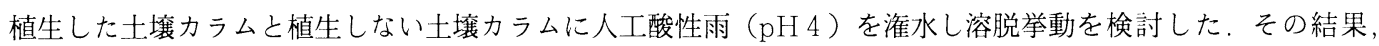
植生土壌では $\mathrm{Ca}, \mathrm{Mg}, \mathrm{Cl}$ の溶脱が著しくなり, 樑さ方向での溶脱したカチオンの量の違いは認められなかった。 これらの結果から酸性雨の溶脱への影響は植物根によって影響されるむのと考えられた。

\section{1. 諸言}

近年, 酸性雨が環境問題として取り上げられ，環境 庁の第一次酸性雨対策調査 ${ }^{11}$ に見られるように土壤・ 植生への影響の研究が土壤の塩基溶脱や植物の而性な どを対象として行なわれてきた。しかし植物を含めた 土㙵の塩基溶脱挙動の把握が植生への影響を定量的に 考える上で重要であるにもかかわらず森林地における 樹幹流や林内，林外雨の違いが注目されている他，植 生土壌系で検討された例（堀内ら ${ }^{2)}(1990)$ ) は極めて 少ない上うに思われる。

そこで, 本研究はその基礎研究として, 植生ポット
と植生をしないポットを用い，模擬酸性雨による塩基 溶脱挙動の違いについて実験的に検討を加えた。

\section{2. 実 験 方 法 \\ 2. 1 試料土壤の特性}

熊本県上益城郡の造成中の森林地より土壤を採取し た（地表より $5 \mathrm{~m}$ ）。 それは火山灰土で赤色をしてお り赤ぼく土に分類される，採取した土壌は風乾して篩 により $2 \mathrm{~mm}$ 以下のものを実験に供した。 土壤の性状を 表 1 に示す.

\section{2 模擬酸性雨}

$0.1 \mathrm{mmol} の \mathrm{~K}_{2} \mathrm{SO}_{4}, \mathrm{KNO}_{3}$ 混合液（イオン交換水

表 1 試料土壌の理化学的性質

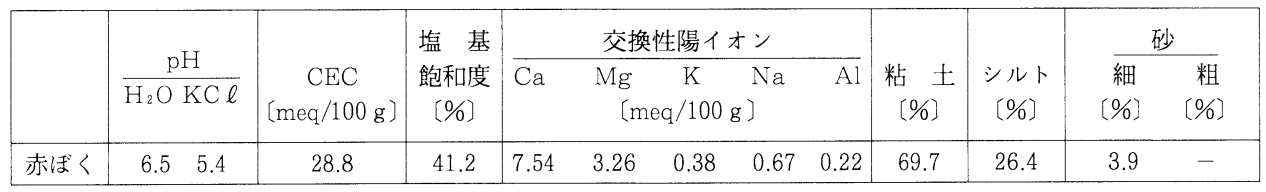

* 熊本大学工学部土木環境工学科 Hiroyuki HARADA, Jafar GHAYOUMIAN, Shigeki NAKAJIMA

$* *$ 通産省工技院名古屋工業試験所 Kazuhiko TANAKA 
で調整）を $\mathrm{HC} \ell て ゙ \mathrm{pH} 4$ に調整した溶液を用いた。 これはNodvin ら 弓 $^{3)}$ 硫酸塩 $\left(\mathrm{Na}_{2} \mathrm{SO}_{4}\right)$ による模擬酸 性雨調整法を参考にした。 また $\mathrm{SO}_{4}^{2-}$ と $\mathrm{NO}_{3}^{-}$の濃度 比は熊本県の公的機関で測定された值を参考とし 1 ：

1 とした。

\section{3 実 験 法}

植生土袞と土袞力ラムをそれぞれ調整する。カカラム は内径 $150 \mathrm{~mm} \times$ 高さ $500 \mathrm{~mm}$ のアクリル製で，そのカラム に土壤を高さ $400 \mathrm{~mm}$ まで充填密度 0.98 で充填した，植 栽および成育の方法は堀内ら ${ }^{2)}$ の方法に従い大豆を力 ラムに成育させた後実験に供した。この際の根はほぼ $300 \mathrm{~mm}$ の深さに達していた。この植生土壤カラムと土 壤カラムをサイフォンによりイオン交換水で飽和させ, そしてこの水を重力排出した後, 模擬酸性雨, イオン 交換水を $500 \mathrm{~mm}$ 相当を潅水した，土㙵溶液は表層から 深さ $10 \mathrm{~cm}$ 毎に挿入した土壌溶液採取器により採取し分 析に供した。 土壌溶液の分析は, 試料溶液を $5 \mathrm{~B}$ 万紙で ろ過した後 $\mathrm{pH}$ ( $\mathrm{pH}$ 電極使用), $\mathrm{SO}_{4}^{2-}$,

$\mathrm{NO}_{3}^{-}$(イオンクロマトグラフィ一使用 : DIONEX-2000i）抢よび $\mathrm{Ca}^{2+}, \mathrm{Mg}^{2+}$, $\mathrm{Na}^{+}, \mathrm{K}^{+}, \mathrm{Al}^{3+}, \mathrm{Fe}^{2+}, \mathrm{Mn}^{2+}$ を測定した （原子吸光分析：HITACHI-6000i 使用, なお $\mathrm{Ca}^{2+}$ の測定では $\mathrm{SO}_{4}^{2-}$ のマスキング 剤として $\mathrm{SrC} \ell$ 2を用いた).

\section{3. 結果亡考察}

\section{1 植生土壤カラムの溶脱挙動}

植生土壤力ラムと土壤力ラムの模擬酸性 雨処理におけるカチオンとアニオンの挙動 を示す（図一1）.

$\mathrm{Ca}^{2+}$ : 植生カラムではカルシゥムの溶脱 が土壤カラムに比べ2.5 4.7倍大きくなっ ておりかつその濃度が50mm潅水毎に増減を 繰り返している.

$\mathrm{Mg}^{2+}$ : 植生カラムでは $200 \mathrm{~mm}$ 潅水まで濃 度の増減を繰り返し $200 \mathrm{~mm}$ 以降, 0.69 0.75

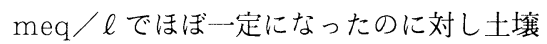
カラムでは $200 \mathrm{~mm}$ まで濃度は増加し, その

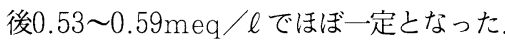

$\mathrm{Na}^{+}$: 土壌力ラムでは $400 \mathrm{~mm}$ 潅水まで 0.26 meq / l から0.38meq / l に増加してそ の後濃度が $0.32 \mathrm{meq} / \ell$ に低下し溶脱が 減少の傾向にある。一方, 植生カラムでは $0.23 \mathrm{meq} / \ell$ から $0.49 \mathrm{meq} / \ell$ まで増加し
濃度の減少は見られなかった。

$\mathrm{K}^{+}$: 多少のばらつきはあるが植生, 土壌カラムとも $0.02 \mathrm{meq} / \ell \sim 0.05 \mathrm{meq} / \ell$ であり，模擬酸性雨成分 濃度から考えると $0.25 \mathrm{meq} / \ell$ 以上が土㙵や植物に吸 着，吸収されたことになる。

$\mathrm{Mn}^{2+}: 50,150,250 \mathrm{~mm}$ 潅水で植生カラムのみ検出さ れた。

$\mathrm{Fe}^{2+}$ : 極く微量（約 $9 \times 10^{-4} \mathrm{meq} / \ell ）$ であるが植 生カラムにおいて $300 \mathrm{~mm}$ 潅水まで検出された。

$\mathrm{A} \ell^{3+}$ : ばらつきが認められるが，傾向としては土壤 カラム ( $\mathrm{pH} 4$ 模擬酸性雨処理) で $100 \mathrm{~mm}$ 潅水から0.004 meq / $\ell$ 程度検出されているのに対し植生カラムで は $150 \mathrm{~mm}$ 降雨から検出され始め $250 \mathrm{~mm}$ 潅水で $0.009 \mathrm{meq} /$ にに達した後減少し $400 \mathrm{~mm}$ 海水では検出されなくなった。 $\mathrm{SO}_{4}^{2-}$ : 模擬酸性雨成分であるが土袞溶液の濃度はイ オン交換水降雨とほぼ同じであり，土壤や植物によっ て吸着，吸収されていることがわかる，また，カラム
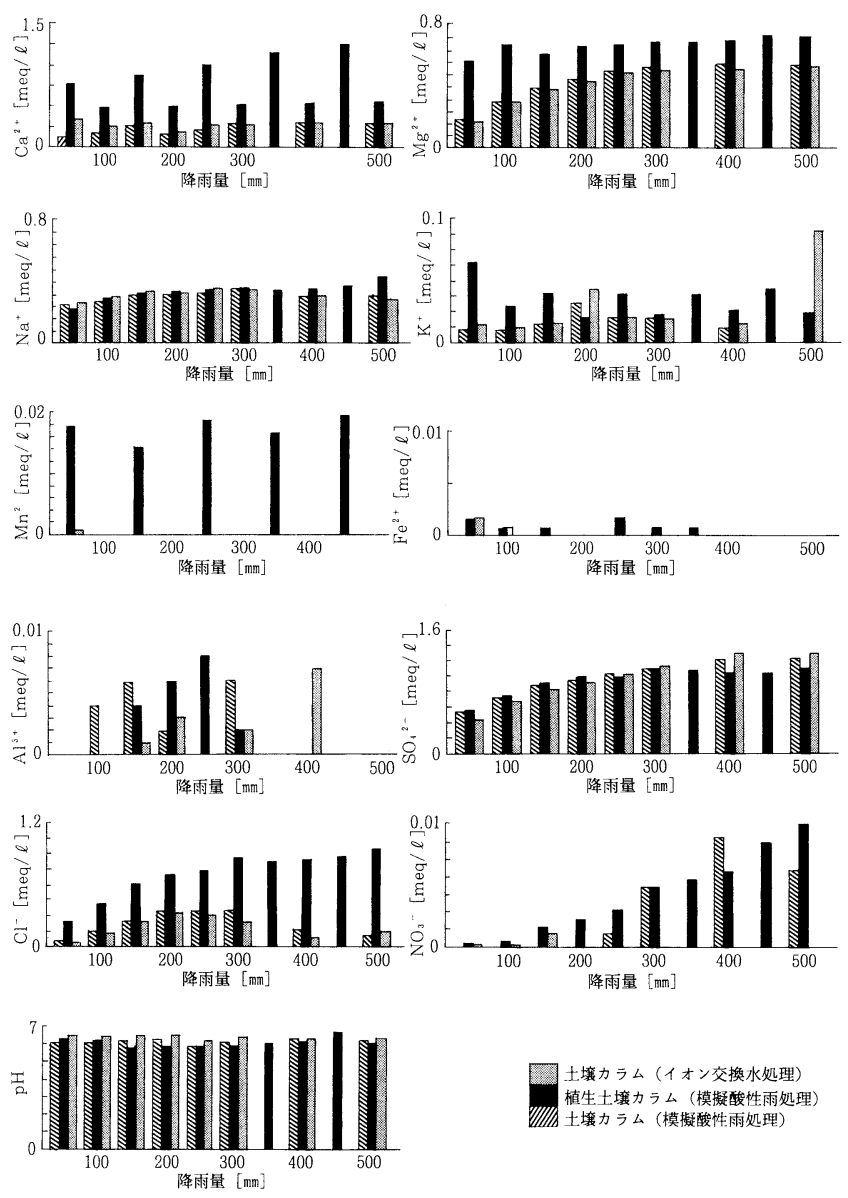

図－1 酸性雨による植生土壌の溶脱挙動 


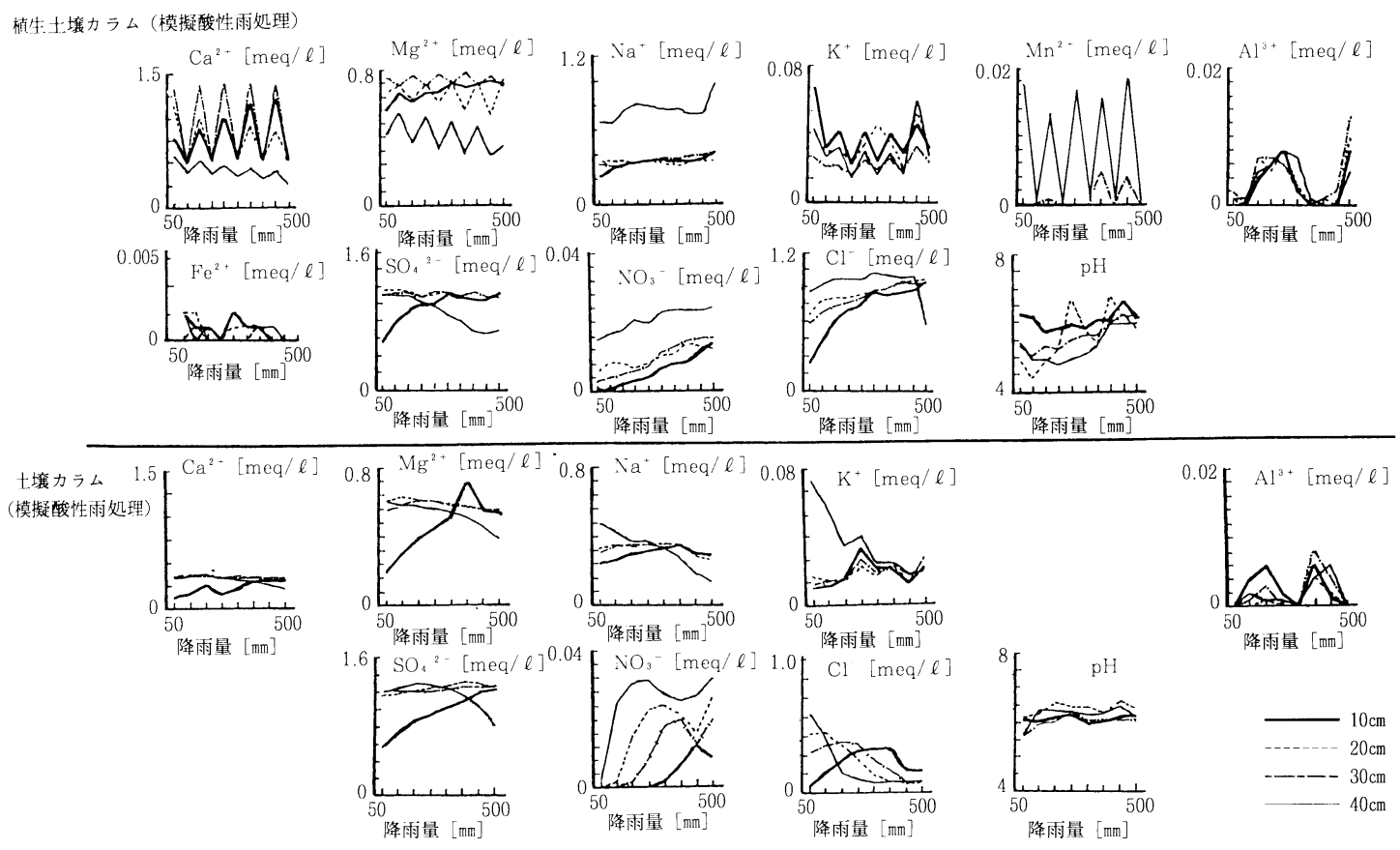

図－２深さ方向での溶脱挙動の違い

間の差は小さい

$\mathrm{NO}_{3}^{-}$: 模擬酸性雨成分で吸着, 吸収が認められるが, $300 \mathrm{~mm}$ 潅水から溶液中の濃度は $0.007 \mathrm{meq} / \ell$ と増加し， 吸着される量が減少していることがわかる。

$\mathrm{pH}$ : カラム間の差はわずかで6.0〜6.2で一定であった.

図－2 に表層から $10 \mathrm{~cm}, 20 \mathrm{~cm}, 30 \mathrm{~cm}, 40 \mathrm{~cm}$ の採取点 おける潅水量と土壌溶液組成の濃度変化を示す。植生 土壤力ラムでは土㙵力ラムと比較して図ー 1 で述べた ように $\mathrm{Ca}^{2+}, \mathrm{Mg}^{2+}, \mathrm{K}^{+}, \mathrm{Mn}^{2+}$ の濃度の増隇がいず れの深さにおいても認められ，加えて $\mathrm{Ca}^{2+}$, $\mathrm{Mg}^{2+}, \mathrm{pH}$ では深さ $40 \mathrm{~cm}$ の採取点の值が他の採取点 に比べ小さくなっている. そして $\mathrm{Cl}^{-}$は溶脱が継続し 溶液中の濃度が増加の傾向にあって土壌力ラムとは逆 の挙動を示す.

植生土㙵での溶脱挙動については欧米で多くの農業 灌溉に関連した移動モデルの研究（D. Melamed ら $(1977)^{4)}$ : source-think モデル C. W. Robbins ら $(1980)^{5)}$ : カチオン交換モデル, W. A. Jury ら $(1977)^{6)}$ : 平衡モデル）がある.これらのモデルは水分移動の式 に土壤一土壌溶液間の関係を適用したもので植物根の 影響や $\mathrm{pH}$ に対する挙動の記述は多くない，本研究の 植生土壤カラムでの溶脱挙動は水素イオンとカチオン の交換，移動，植物根による吸収，吸収されない成分 の下方移動 ${ }^{5)}$ に起因し, そのため $\mathrm{Ca}^{2+}, \mathrm{Mg}^{2+}$ など
の増減が認められたものと思われる。そしてその溶脱 量, 特に $\mathrm{Ca}^{2+}, \mathrm{Cl}^{-}$が土壌力ラムに比して大きくなっ たのは攪乱土で同一条件でカラムに充填したが植生土 褰カラムでは植物根によって粒団が形成されその粒団 内細孔によって $500 \mathrm{~mm}$ の潅水では著しい $\mathrm{Ca}^{2+}$ の溶脱がお こり，イオンバラン $\mathrm{Cl}^{-}$が溶脱するあのと考えられる。

\section{2 土㗒溶液のイオン組成}

図ー 3 は各力ラムにおける土壊溶液の組成を示す． 植生土䁃力ラムでは溶液中のカチオンはほぼ $\mathrm{Ca}^{2+}$, $\mathrm{Mg}^{2+}, \mathrm{Na}^{+}$により構成される。採取点 $10 \mathrm{~cm}$ における 土㙲溶液では $\mathrm{Na}^{+}$が 5 割以上を占め，その割合は採 取点 $40 \mathrm{~cm}$, 土壤力ラム（模擬酸性雨, イオン交換水） に比して高くなっている. カチオンの総量は土壤カラム ではほぼ $\mathrm{SO}_{4}^{2-}$ に相当するが，植生土壤力ラムでは $\mathrm{Cl}^{-}$ が溶脱し $\mathrm{Cl}^{-}$と $\mathrm{SO}_{4}^{2-}$ の合計にバランスするようになる.

\section{3 水素イオン負荷量の影響}

図ー4 は水素イオン負荷量に対する総力チオン溶脱 量を示したものである，植生土䗙力ラムでは $10 \mathrm{~cm}$ と $40 \mathrm{~cm}$ における差異は少ない。これは $10 \mathrm{~cm}$ の採取点では $40 \mathrm{~cm}$ の採取点に比べ $\mathrm{Ca}^{2+}$ の溶脱が大きいのに対し， $40 \mathrm{~cm}$ の採取点では $\mathrm{Na}^{+}$の溶脱が大きくなっており全 体として溶脱量の差が小さくなったためである。そし

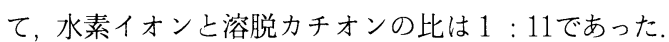
また土壌カラムでは $10 \mathrm{~cm} て ゙ ~ 1: 10,40 \mathrm{~cm}$ で $1: 8$ とな 
土壤力ラム（模擬酸性雨処理）

$100 \mathrm{~mm}$ 降雨 $\quad 10 \mathrm{~cm}$ $40 \mathrm{~cm}$

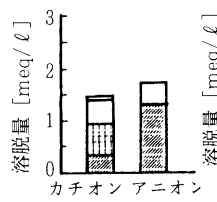

$250 \mathrm{~mm}$ 降雨
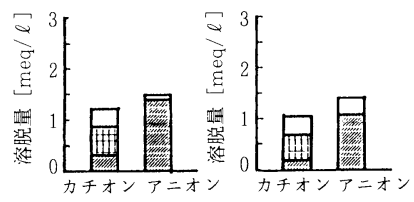

$500 \mathrm{~mm}$ 降雨
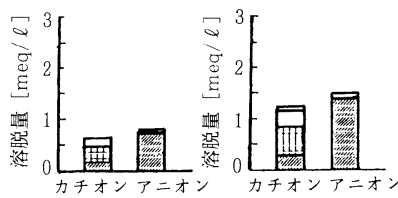

植生土埪力ラム（模擬酸性雨処理）

$10 \mathrm{~cm}$
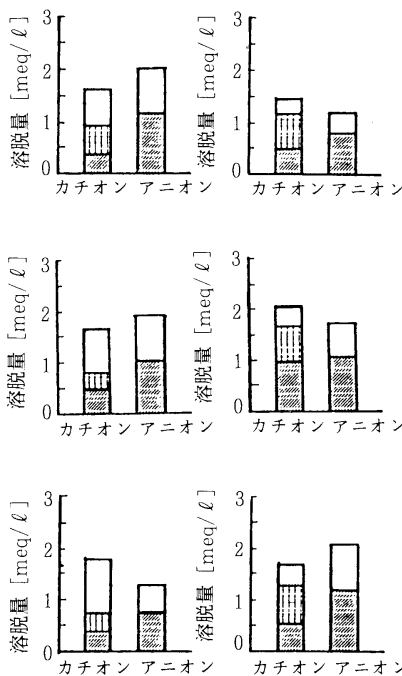

図-3 土壌溶液組成
土壤カラム(イオン交換水処理)

$10 \mathrm{~cm}$

$40 \mathrm{~cm}$
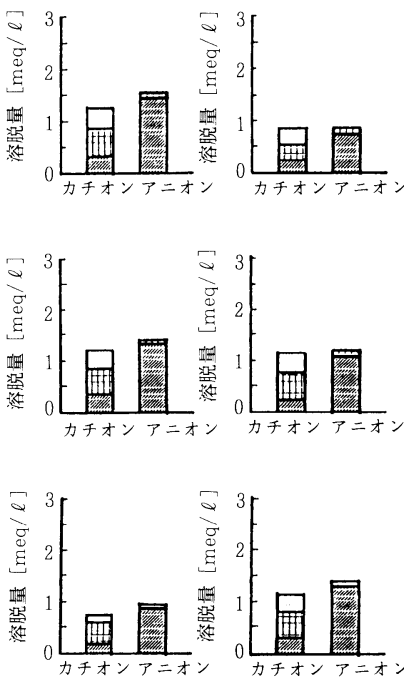

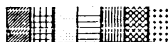

$\mathrm{Ca}^{2+} \mathrm{Na}^{+} \mathrm{Mn}^{2+} \mathrm{Al}^{3}$
$\mathrm{Mg}^{2+} \mathrm{K}^{+} \mathrm{Fe}^{2+}$

政果

$\mathrm{SO}_{4}^{2}{ }^{-} \mathrm{Cl}^{-} \mathrm{NO}_{3}^{-}$
植生土壤カラム
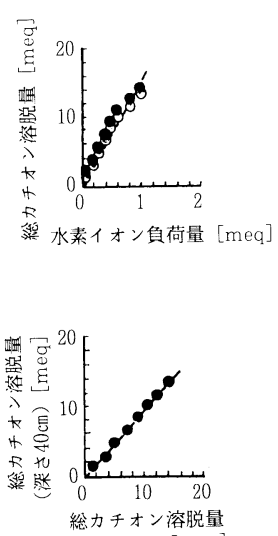

(樑さ $10 \mathrm{~cm})[\mathrm{meq}]$ (模擬酸性雨处理)
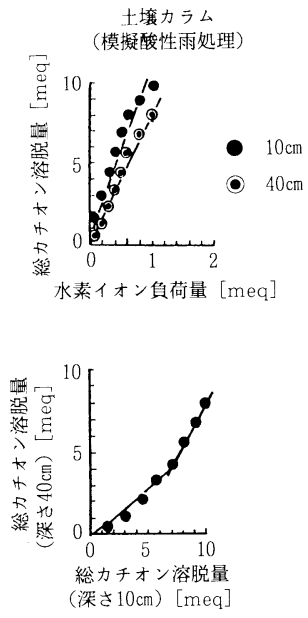

図－4 水素イオン負荷量と総力チオン溶脱量の関係

り，土壤カラムでは表層で塩基の溶脱が進行している ことが分かる。

\section{4. ま と め}

植生土壌（火山灰土一赤ぼく土）では酸性雨（pH 4）により植物根圈で, $\mathrm{Ca}^{2+}, \mathrm{Mg}^{2+}, \mathrm{Na}^{+}$の塩基溶 脱が促進され，そして潅水に伴う土壌溶液中の $\mathrm{Ca}^{2+}$, $\mathrm{Mg}^{2+}$ 濃度は増減を繰り返した，総塩基溶脱量では深 さ方向の差異は認められなかった。この独特な挙動は
植物根により土壌間隙が変化したことに起因すると考 えており, 今後土壌構造による影響や植物の個体の吸 収など影響について検討を加えて行く予定である。

\section{謝 辞}

本研究に御協力を頂いた本研究室卒業生 奥村知明 君 (現 熊本県庁), 久保賢二君 (現 広島市) に感 謝いたします。

\section{参 考 文 献}

1 ）環境庁水質保全局土壌農薬課監修（1990）：酸性雨一土 壌・植生への影響, 公害研究対策センター

2 ）堀内将人, 井上頼輝（1990：植生土壤中の污染物質の挙 動に関する実験的考察, 土木学会第45回年次学術講演会, II -410 , pp.872 873

3) Nodvin S. C., Driscoll C. T., Linkes G. E (1986): Theeffectsof pH on sulfate adsorption by a forst soil, Soil Science, Vol.142, No. 2, pp.69 74

4) Melamed D., Hanks R. J., Willardson L. S. (1977): Model of a salt flow in soil with a source-sink term, Soil. Sci. Soc. Am J., Vol.41, pp.29 33

5 ) Robbinson C. W., Jurink J. J., Wagnet R. J. (1980): Calculating cation exchange in a salt transport model, Soil Sci. Soc. Am. J., Vol.44, pp.195 1198

Soil Sci. Amer. Proc. Vol.33, pp.827 832

6) Jury W. A., Frenkel H., Devitt D., Stolzy H. (1971) Transient changes in the soil-water system from irrigation with saline wate: I Theory, Soil Sci. Soc. Am. J. Vol. 42 , pp. $579 \sim 584$ 